\title{
PENGARUH TAX AVOIDANCE TERHADAP NILAI PERUSAHAAN
}

\author{
Gina Harventy \\ Prodi Akuntansi FEB Universitas Muhammadiyah Malang \\ Jl. Raya Tlogomas 246 Malang \\ email: ginaharventy@gmail.com
}

\section{$A B S T R A C T$}

The purpose of this study is to examine the relation between tax avoidance and the firm value. Tax avoidance is convinced as wealth transfer from the government to companies which has obligation to enhance firm value. This study uses annual Cash ETR as a proxy for tax avoidance and Tobin's $Q$ as a proxy for firm value. The sample of this research is manufacture companies listed in Indonesia Stock Exchange for the period 2013 to 2015. Using purposive sampling technique, we find 35 firms with 105 observations. The statistical methods used in this research is Linear Regressions Analysis. The empirical results showed that the tax avoidance effect on firm value.

Keywords: Firm Value, Manufacturing Firm, Tax Avoidance

\section{PENDAHULUAN}

Teory keagenan mendeskripsikan hubungan antara pemegang saham (shareholders) sebagai principal dan pengelola atau manajemen perusahaan sebagai agen. Manajemen merupakan pihak yang dikontrak oleh pemegang saham untuk bekerja demi kepentingan para pemegang saham. Oleh sebab itu pihak manajemen harus mempertanggungjawabkan pekerjaan dan kepercayaan (trust) yang diberikan pemegang saham. Hal ini berarti, agen bertanggung jawab dalam mengelola dana perusahaan yang dipercayakan kepadanya, dan perusahan seoptimal mungkin untuk terus meningkatkan nilai perusahaan.

Perusahaan pada umumnya berusaha untuk meningkatkan nilai perusahaan setiap periode. Karena tingginya nilai perusahaan, yang tercermin dalam harga saham yang akan dapat meningkatkan kemakmuran bagi para pemegang saham. Hal ini memberikan dampak para pemegang saham agar tetap mempertahankan investasinya dan calon investor tertarik menginvestasikan modalnya kepada perusahaan tersebut (Ilmiani dan Sutrisno, 2013). Nilai perusahaan menjadi hal yang penting bagi investor, karena merupakan indikator bagi pasar untuk menilai perusahaan secara keseluruhan atau dapat dikatakan nilai perusahaan merupakan harga yang dibayar oleh calon pembeli jika perusahaan tersebut dijual.

Berbagai upaya dilakukan pihak manajemen untuk meningkatkan nilai perusahaan, Salah satu strategi yang dilakukan perusahaan adalah dengan menerapkan strategi perencanaan pajak (tax planning). Menurut Suandy (2011) perencanaan pajak merujuk pada proses merekayasa usaha dan transaksi wajib pajak supaya utang pajak berada dalam jumlah yang minimal tetapi masih dalam bingkai peraturan perpajakan. Salah satu strategi umum dalam melakukan perencanaan pajak adalah tax avoidance.

Tax avoidance atau penghindaran pajak adalah proses pengendalian tindakan agar terhindar dari konsekwensi pengenaan pajak yang tidak dikehendaki. Karena tindakan tax avoidance masih dalam koridor perundang-undangan (lawfull fashion). Yaitu dengan cara melakukan efisiensi beban pajak dengan menghindari pengenaan pajak melalui transaksi yang bukan merupakan objek pajak. Hal tersebut berarti tidak ada suatu pelanggaran hukum yang dilakukan dan sebaliknya

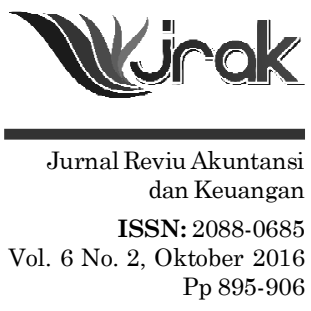




\section{Pengaruh \\ Tax}

Avoidance...

896 akan diperoleh penghematan pajak dengan cara mengatur tindakan yang menghindarkan aplikasi pengenaan pajak melalui pengendalian fakta-fakta sedemikian rupa sehingga terhindar dari pengenaan pajak yang lebih besar atau sama sekali tidak kena pajak (Zain, 2007).

Tindakan tax avoidance yang dilakukan perusahaan dapat meningkatkan nilai perusahaan, karena laba yang di dapat oleh perusahaan akan semakin besar. Secara tradisional, dipercaya bahwa penghindaran pajak korporasi merupakan transfer kekayaan dari pemerintah kepada korporasi dan harus menambah nilai perusahaan (Chen dkk., 2013). Akan tetapi penghindaran pajak bukanlah tanpa biaya, biaya langsung seperti biaya implementasi, kehilangan reputasi, ancaman hukuman dan lain-lain harus ditanggung oleh perusahaan. Biaya yang dikeluarkan perusahaan dalam mengimplementasikan praktik penghindaran pajak seharusnya tidak lebih besar dari manfaat yang akan diterima. Menurut perspektif agensi penghindaran pajak menunjukkan bahwa penghindaran pajak tidak selalu diinginkan oleh pemegang saham karena terdapat biaya yang harus dikeluarkan meliputi biaya yang berkaitan langsung dengan kegiatan penghindaran pajak dan biaya tidak langsung yang mungkin lebih besar dari manfaat dalam melakukan praktik penghindaran pajak. Oleh karena itu, penghindaran pajak yang dilakukan oleh perusahaan harus mempertimbangkan cost dan benefit.

Hubungan antara tax avoidance dengan nilai perusahaan menjadi sebuah hal penting, tetapi masih dalam perdebatan. Bukti empiris sekarang menunjukkan bahwa reaksi investor terhadap penghindaran pajak masih belum jelas. Desai dan Dharmapala (2009) menemukan bahwa secara keseluruhan akibat aktivitas penghindaran pajak perusahaan terhadap nilai perusahaan tidak signifikan berbeda dari nol. Efeknya positif hanya jika untuk perusahaan dengan level kepemilikan institusi yang tinggi. Akan tetapi hasil penelitian yang dilakukan oleh Chen dkk. (2013) di China menemukan hubungan negatif antara penghindaran pajak dan nilai perusahaan, dan hubungan negatif ini dapat dikurangi dengan transparansi informasi.

Penelitian kali ini mereplikasi penelitian yang dilakukan oleh Ilmiani dan Sutrisno (2014) yang bertujuan untuk menguji pengaruh Tax Avoidance terhadap nilai perusahaan. Sampel dalam penelitian ini adalah perusahaan manufaktur yang terdaftar di Bursa efek Indonesia tahun 2013-2015. Dengan adanya penelitian ini, penulis berharap dapat memberikan manfaat antara lain dapat dijadikan bukti empiris dan menambah literatur ilmu pengetahuan khususnya dibidang tax avoidace, dan nilai perusahaan yang masih dalam perdebatan. Penelitian ini juga diharapkan menjadi panduan dalam melakukan manajemen pajak, yang sesuai dengan prinsip tax avoidance sehingga tidak melanggar peraturan perundangundangan. Selain itu dapat dijadikan referensi akan pentingnya manajemen pajak, agar pajak terutang perusahaan menjadi lebih efektif dan efisien. Berdasarkan uraian di atas, maka dalam penelitian ini diambil judul: "Pengaruh Tax Avoidance Terhadap Nilai Perusahaan.”

\section{TINJAUAN KEPUSTAKAAN}

\section{a. Teori Keagenan}

Jensen dan Meckling (1976) mendefinisikan teori agensi sebagai kontrak antara satu atau beberapa orang principal yang mendelegasikan wewenang kepada orang lain (agent) untuk mengambil keputusan dalam menjalankan perusahaan. Teori keagenan berfokus pada pada hubungan antara dua pelaku yang saling berbeda kepentingan yaitu antara agen dan prinsipal. Teori keagenan menjelaskan pemisahan antara manajemen (agen) dan pemegang saham (prinsipal). Tujuan pemisahan ini adalah agar tecapai keefektifan dan keefisienan dalam mengelola perusahaan dengan mempekerjakan agen terbaik dalam mengelola perusahaan. Akan tetapi agen mungkin akan mementingkan kepentingan diri sendiri dengan 
mengorbankan prinsipal, disisi lain prinsipal menginginkan return yang tinggi atas sumber daya yang telah diinvestasikan.

\section{b. Pajak}

Menurut Pasal 1 UU No. 28 Tahun 2007, pajak adalah kontribusi wajib kepada negara yang terutang oleh orang pribadi atau badan yang bersifat memaksa berdasarkan undang-undang dengan tidak mendapatkan imbalan secara langsung dan digunakan untuk keperluan negara bagi sebesar-besarnya kemakmuran rakyat. Menurut Resmi (2013) beberapa ciri yang melekat pada definisi pajak antara lain:

1. Pajak dipungut berdasarkan atau dengan kekuatan undang-undang serta aturan pelaksanaannya.

2. Dalam pembayaran pajak tidak dapat ditunjukkan adanya kontraprestasi individual oleh pemerintah.

3. Pajak dipungut oleh negara baik pemerintah pusat maupun pemerintah daerah.

4. Pajak diperuntukkan bagi pengeluaran-pengeluaran pemerintah, yang bila dari pemasukkannya masih terdapat surplus digunakan untuk membiayai public investment.

Menurut Mardiasmo (2011) agar pemungutan pajak tidak menimbulkan hambatan atau perlawanan, maka pemungutan pajak harus memenuhi syarat sebagai berikut:

1. Pemungutan pajak harus adil (Syarat Keadilan)

2. Sesuai dengan tujuan hukum, yakni mencapai keadilan, undang-undang dan pelaksanaan pemungutan harus adil. Adil dalam perundang-undangan diantaranya mengenakan pajak secara umum dan merata, serta disesuaikan dengan kemampuan masing-masing.

3. Pemungutan pajak harus berdasarkan undang-undang (Syarat Yuridis)

4. Di Indonesia, pajak diatur dalam UUD 1945 pasal 23 ayat 2. Hal ini memberikan jaminan hukum untuk menyatakan keadilan, baik bagi negara maupun warganya.

5. Tidak mengganggu perekonomian (Syarat Ekonomis)

6. Pemungutan pajak tidak boleh mengganggu kelancaran kegiatan produksi maupun perdagangan, sehingga tidak menimbulkan kelesuan perekonomian masyarakat.

7. Pemungutan pajak harus efisien (Syarat Finansiil)

8. Sesuai fungsi budgetair, biaya pemungutan pajak harus dapat ditekan sehingga lebih rendah dari hasil pemungutannya.

9. Sistem pemungutan pajak harus sederhana

10. Sistem pemungutan yang sederhana akan memudahkan dan mendorong masyarakat dalam memenuhi kewajiban perpajakannya.

Pemungutan pajak kepada wajib pajak mempunyai dua fungsi. Pajak berfungsi sebagai sumber keuangan negara yang digunakan untuk membiayai pengeluaran rutin maupun pembangunan. Sebagai sumber keuangan negara pemerintah yang dalam hal ini sebagai fiskus atau pemungut pajak berupaya untuk memasukkan uang sebanyak-banyakknya untuk kas negara. Upaya tersebut ditempuh dengan cara ekstensifikasi maupun intensifikasi pemungutan melalui penyempurnaan peraturan berbagai jenis pajak seperti $\mathrm{PPh}, \mathrm{PPN}, \mathrm{PPnBM}$, PBB dan lain-lain. Fungsi kedua dari pajak sebagai pengatur (regulered), artinya pajak sebagai alat untuk mengatur atau melaksanakan kebijakan pemerintah 


\section{Pengaruh \\ Tax}

Avoidance... dalam bidang sosial dan ekonomi, serta mencapai tujuan tujuan tertentu diluar bidang keuangan.

Negara memungut pajak tidaklah tanpa alasan. Terdapat beberapa teori yang menjelaskan hak negara dalam memungut pajak dari masyarakat. Teoriteori tersebut menurut Resmi (2013) adalah sebagai berikut:

898

Negara melindungi keselamatan jiwa, harta benda dan hak-hak rakyatnya. Oleh karena itu rakyat harus membayar pajak yang diibaratkan sebagai suatu premi asuransi karena memperoleh jaminan perlindungan tersebut.

2. Teori Kepentingan

Pembagian beban pajak kepada rakyat didasarkan pada kepentingan masingmasing orang. Semakin besar kepentingan seseorang terhadap negara, makin tinggi pajak yang harus dibayarkan.

3. Teori Daya Pikul

Beban pajak untuk semua orang harus sama beratnya, artinya pajak harus dibayar sesuai dengan daya pikul masing-masing orang.

4. Teori Bakti

Dasar keadilan pemungutan pajak terletak pada hubungan rakyat dengan negaranya. Sebagai warga negara yang berbakti, rakyat harus selalu menyadari bahwa pembayaran pajak adalah sebagai suatu kewajiban.

5. Teori Asas Daya Beli

Dasar keadilan terletak pada akibat pemungutan pajak. Maksudnya memungut pajak berarti menarik daya beli dari rumah tangga masyarakat untuk rumah tangga negara. Selanjutnya negara akan menyalurkan kembali ke masyarakat dalam bentuk pemeliharaan kesejahteraan masyarakat. Dengan demikian kepentingan seluruh masyarakat lebih diutamakan.

\section{c. Manajemen Pajak}

Pajak merupakan beban yang harus ditanggung oleh perusahaan sebagai bentuk kewajiban kehidupan bernegara. Pajak merupakan beban perusahaan dan akan mengurangi laba yang diterima oleh perusahaan. Oleh karena itu, perusahaan seringkali melakukan berbagai upaya untuk meminimalkan beban pajaknya. Salah satu yang sering dilakukan adalah menerapkan manajemen pajak. Manajemen pajak atau perencanaan pajak adalah usaha yang dilakukan oleh manajemen berkaitan dengan kewajiban perpajakan dengan tujuan utang pajak yang dibayar menjadi efektif dan efisien. Menurut Zain (2008) perencanaan pajak (tax planning) adalah proses mengorganisasi usaha wajib pajak atau kelompok wajib pajak sedemikian rupa sehingga utang pajaknya, baik pajak penghasilan maupun pajak-pajak lainnya, berada dalam posisi yang paling minimal, sepanjang hal ini dimungkinkan oleh ketentuan peraturan perundang-undangan perpajakan maupun secara komersil. Sedangkan menurut Suandy (2011) perencanaan perpajakan merujuk pada proses merekayasa usaha dan transaksi Wajib Pajak supaya utang pajak berada dalam jumlah yang minimal tetapi masih dalam bingkai peraturan perpajakan.

Suandy (2011) menjelaskan bahwa tujuan yang diharapkan dengan adanya manajemen pajak adalah:

1. Menerapkan peraturan perpajakan secara benar

2. Usaha efisiensi untuk mencapai laba dan likuiditas yang seharusnya.

\section{d. Tax avoidance}

Menurut Anderson dalam Zain (2008) penghindaran pajak (tax avoidance) adalah cara mengurangi pajak yang masih dalam batas ketentuan peraturan perundang-undangan perpajakan dan dapat dibenarkan, terutama melalui peren- 
canaan pajak. Sedangkan Wang (2010) mendefinisikan tax avoidance sebagai pengurang pajak eksplisit per dolar dari laba akuntansi sebelum pajak. Dipercaya bahwa penghindaran pajak perusahaan menggambarkan transfer kekayaan dari pemerintah kepada korporasi dan harus menambah nilai perusahaan (Chen dkk., 2013). Menurut Dyreng dkk. (2008) penting untuk menekankan bahwa penghindaran pajak tidak selalu berarti perusahaan terlibat dalam suatu yang tidak benar. Ada banyak ketentuan atau celah dalam peraturan perpajakan yang memungkinkan dan mendorong perusahaan untuk mengurangi tarif pajaknya. Terdapat perbedaan antara penghindaran pajak (tax avoidance) dengan penyelundupan pajak (tax evasion). Tax avoidance tidak melanggar perundang-undangan dan hanya memanfaatkan celah kelemahan yang ada dalam undang-undang tersebut. Sedangkan tax evasion merupakan usaha yang dilakukan oleh perusahaan untuk menghindari kewajiban perpajakannya dengan melanggar peraturan perundang-undangan yang ada.

Menurut Suandy (2011) terdapat beberapa faktor yang memotivasi wajib pajak untuk melakukan penghematan pajak dengan ilegal:

1. Jumlah pajak yang harus dibayar. Semakin besar jumlah pajak yang harus dibayar, semakin besar kecenderungan wajib pajak untuk melakukan pelanggaran.

2. Biaya untuk menyuap fiskus. Semakin kecil biaya untuk menyuap fiskus, semakin besar kecenderungan wajib pajak untuk melakukan pelanggaran.

3. Kemungkinan untuk ketahuan. Semakin kecil kemungkinan suatu pelanggaran terdeteksi, semakin besar kecenderungan wajib pajak untuk melakukan pelanggaran.

4. Besar sanksi. Semakin ringan sanksi yang dikenakan terhadap pelanggaran, semakin besar kecenderungan wajib pajak untuk melakukan pelanggaran.

Suandy (2011) menjelaskan setidak-tidaknya terdapat tiga hal yang harus diperhatikan dalam suatu perencanaan pajak, yaitu:

1. Tidak melanggar ketentuan perpajakan. Bila suatu perencanaan pajak dipaksakan dengan melanggar ketentuan perpajakan, bagi wajib pajak merupakan risiko pajak yang sangat berbahaya dan justru mengancam keberhasilan perencanaan pajak tersebut.

2. Secara bisnis masuk akal, karena perencanaan pajak merupakan bagian yang tidak terpisah dari perencanaan menyeluruh (global strategy) perusahaan, baik jangka panjang maupun jangka pendek. Oleh karena itu, perencanaan pajak yang tidak masuk akal akan memperlemah perencanaan itu sendiri.

3. Bukti-bukti pendukungnya memadai, misalnya dukungan perjanjian (agreement), faktur (invoice) dan juga perlakuan akuntansinya (accounting treatment).

\section{e. Nilai Perusahaan}

Tujuan utama perusahaan saat ini adalah meningkatkan nilai perusahaan yang tercermin dari kemakmuran pemilik atau pemegang saham perusahaan. Nilai perusahaan dapat didefinisikan sebagai nilai pasar karena nilai perusahaan dapat memberikan kemakmuran pemegang saham secara maksimum apabila harga saham meningkat. Kenaikan harga saham akan memberikan keuntungan dan kemakmuran bagi pemegang saham (Bringham \& Houston, 2006)

Salah satu alternatif yang digunakan dalam menilai nilai perusahaan adalah dengan menggunakan Tobin's Q dikembangkan oleh James Tobin (1967). Tobin's $\mathrm{Q}$ dinilai dapat memberikan informasi yang paling baik, karena rasio ini dapat menjelaskan berbagai fenomena yang terjadi dalam kegiatan perusahaan seperti terjadinya perbedaan crossectional dalam pengambilan keputusan investasi. 


\section{Pengaruh \\ Tax}

Avoidance...
Semakin besar nilai Tobin's Q maka semakin besar nilai perusahaan dan mengindikasikan perusahaan memiliki prospek yang baik. Hal ini karena nilai pasar aset perusahaan lebih besar dibandingkan nilai buku aset perusahaan yang berarti semakin besar kerelaan investor untuk mengeluarkan pengorbanan yang lebih untuk memiliki perusahaan tersebut.

Nilai perusahaan mengindikasikan tingkat kemakmuran yang didapat oleh pemegang saham. Semakin tinggi harga saham, maka semakin tinggi kemakmuran pemegang saham. Pemegang saham akan melakukan segala upaya untuk meningkatkan nilai perusahaan sehingga tingkat kesejahteraannya meningkat. Bagi perusahaan yang telah go public, maka nilai perusahaannya akan tercermin dari harga saham yang terdapat di bursa. Nilai perusahaan dapat meningkat jika perusahaan dikelola oleh orang yang kompeten.

\section{PENGEMBANGAN HIPOTESIS}

Para pemegang saham menginginkan supaya perusahaaan memiliki nilai perusahaan yang maksimal. Investor akan cenderung menanamkan modalnya dengan melihat laba bersih perusahaan yang akan menggambarkan nilai perusahaan itu sendiri, sehingga manajer secara tidak langsung dituntut bagaimana untuk memaksimalkan nilai perusahaan tersebut salah satu caranya dengan melakukan penghindaran pajak. Desai dan Dharmapala (2009) mengatakan sudut pandang tradisional terhadap penghindaran pajak perusahaan menunjukkan bahwa nilai pemegang saham seharusnya meningkat seiring dengan aktifitas penghindaran pajak perusahaan, namun hal itu berbeda bila dilihat dari sudut pandang manajer perusahaan terhadap penghindaran pajak, dimana perusahaan akan memberikan prediksi yang berbeda. Perspektif manajer atas penghindaran pajak mengatakan penghindaran pajak tidak selalu diinginkan oleh pemegang saham karena terdapat biaya yang harus dikeluarkan di waktu yang akan datang, seperti biaya yang dikeluarkan untuk perencanaan pajak, tambahan biaya kepatuhan (Wang, 2010).

$\mathrm{H}_{1}$ : Tax avoidance berpengaruh pada nilai perusahaan.

\section{METODOLOGI}

\section{Variabel Penelitian dan Definisi Operasional Variabel}

Pada penelitian ini variabel-variabel yang digunakan yaitu variabel dependen dan variabel independen. Variabel dependen dalam penelitian ini adalah nilai perusahaan. Variabel independen yang digunakan adalah tax avoidance.

a. Nilai Perusahaan

Nilai perusahaan berperan sebagai variabel dependen dalam penelitian ini. Variabel dependen atau variabel terikat merupakan variabel yang dipengaruhi oleh variabel independen atau variabel bebas. Perusahaan menjalankan usahanya dengan tujuan agar dapat terus beroperasi dan meningkatkan nilai perusahaan. Nilai persuhaan yang sudah go public tercermin dari harga saham yang terdapat di bursa. Nilai perusahaan dinilai berdasarkan rasio Tobin's Q pada tanggal 31 Desember untuk melihat reaksi penghindaran pajak diakhir periode pengamatan. Tobin's Q yang diukur dengan rumus berikut:

Tobins $\mathrm{Q}: \frac{\mathrm{MVE}+\mathrm{D}}{\mathrm{BVE}+\mathrm{D}}$ 
Tobin's Q : Nilai perusahaan

MVE : Nilai Pasar Ekuitas (Market Value of Equity), merupakan perkalian antara nilai pasar saham diakhir periode dengan jumlah saham yang beredar diakhir periode.

BVE : Nilai Buku Ekuitas (Book Value of Equity), merupakan selisih antara total aset perusahaan dengan total kewajiban.

: Nilai buku dari total utang perusahaan dikhir periode.

b. Penghindaran Pajak

Dalam penelitian ini penghindaran pajak (tax avoidance) berfungsi sebagai variabel independen. Variabel independen adalah variabel yang memengaruhi variabel dependen. Penghindaran pajak (tax avoidance) merupakan usaha yang dilakukan oleh perusahaan untuk mengurangi beban pajaknya. Tax avoidance dilakukan dengan memanfaatkan celah-celah yang ada dalam peraturan perundang-undangan. Penelitian terbaru mengukur tax avoidance menggunakan Cash Effective Tax Rates (Cash_ETR) yang dikembangkan oleh Dyreng dkk. Cash Effective Tax Rate diperoleh dengan membagi beban pajak (pajak yang dibayar) oleh perusahaan dengan jumlah laba perusahaan sebelum pajak. Menurut Dyreng dkk. (2008) perusahaan yang melakukan tax avoidance mempunyai Cash_ETR yang kecil. Berikut adalah persamaan yang digunakan dalam mengukur tax avoidance:

Cash_ETR $=\frac{\sum \text { cash tax paid }}{\sum \text { pretax income }}$

Keterangan:

Cash_ETR : Effective Tax Rates sebagai indikator tax avoidance

Cash Tax Paid : Beban pajak yang dibayar oleh perusahaan (Didapat dari laporan arus kas konsolidasian)

Pretax Income : Laba perusahaan sebelum pajak (Laporan Laba Rugi Komprehensif Konsolidasian)

\section{Populasi dan Sampel Penelitian}

1. Populasi merupakan seluruh karakteristik yang menjadi objek penelitian, dimana karakteristik tersebut berkaitan dengan seluruh kelompok orang, peristiwa, atau benda yang menjadi pusat perhatian bagi peneliti. Populasi dalam penelitian ini adalah perusahaan Manufaktur yang terdaftar di Bursa Efek Indonesia pada periode tahun 2013-2015.

2. Sampel adalah bagian dari populasi yang dipercaya dapat mewakili karakteristik populasi secara keseluruhan. Pengambilan sampel dalam penelitian ini dilakukan dengan metode purposive sampling, yaitu pengambilan sampel berdasarkan pertimbangan subyektif peneliti, dimana terdapat syarat yang harus dipenuhi oleh sampel Adapun kriteria yang harus dipenuhi oleh sampel dalam penelitian ini adalah sebagai berikut:

a. Perusahaan terdaftar dalam Bursa Efek Indonesia pada periode tahun 2010 sampai 2013.

b. Perusahaan mengeluarkan laporan keuangan yang dipublikasikan pada periode tahun 2010 sampai 2013.

c. Perusahaan memiliki laba sebelum pajak yang bernilai positif pada periode tahun 2010 sampai 2013.

d. Data harga saham tersedia selama periode pengamatan.

e. Perusahaan memiliki Cash_ETR tahunan antara $0-100$ persen. 


\section{Pengaruh \\ Tax}

Avoidance... f. Perusahaan menerbitkan laporan keuangan per tanggal 31 Desember.

g. Perusahaan menerbitkan laporan keuangan dalam mata uang Rupiah. Berdasar kriteria tersebut diperoleh sampel penelitian sebanyak 105 sampel.

\section{Jenis dan sumber data}

Data yang digunakan dalam penelitian ini adalah data sekunder, yaitu data yang telah ada dan diambil dari pihak ketiga. Data diperoleh dari laporan tahunan perusahaan yang dipublikasikan di Bursa Efek Indonesia melalui www.idx.co.id.

\section{Metode Analsis}

a. Teknik Analisis

1. Statistik Deskriptif

Statistik deskriptif digunakan untuk mendeskripsikan atau menggambarkan data yang dilihat dari nilai rata-rata (mean), standar deviasi, varians, sum, maksimum, minimum, range, kurtosis dan skewness, dan sebagainya (Ghozali, 2013).

2. Uji Asumsi Klasik

Agar model yang digunakan dapat memberikan hasil yang representatif, maka dilakukan uji asumsi klasik pada model untuk menguji hipotesis yang diajukan. Model yang dibuat dalam penelitian harus memenuhi asumsi dasar yaitu:, uji normalitas, uji heterokedastisitas dan uji autokorelasi.

a. Uji Normalitas

Uji normalitas dilakukan untuk mengetahui apakah variabel berdistribusi normal atau tidak. Uji ini diperlukan untuk melakukan uji f dan uji t yang mengasumsikan bahwa nilai residual mengikuti distribusi normal.

b. Uji Heteroskedastisitas

Uji heteroskedastisitas bertujuan untuk menguji apakah dalam model regresi terjadi ketidaksamaan variance dari residual satu pengamatan ke pengamatan lain, jika variance dari residual satu pengamatan ke pengamatan lain berbeda maka disebut heteroskedastisitas (Ghozali, 2013). Pada penelitian ini menggunakan grafik scatterplot untuk menguji heteroskedastisitas. Dasar pengambilan keputusan untuk uji heteroskedastisitas:

a. Jika ada pola tertentu, seperti titik yang ada membentuk pola tertentu teratur (bergelombang, melebur kemudian menyempit), maka mengindikasikan telah terjadi heteroskedastisitas.

b. Jika tidak ada pola yang jelas, serta titik-titik menyebar diatas dan dibawah angka 0 pada sumbu Y, maka tidak terjadi heteroskedastisitas.

c. Uji Autokorelasi

Uji autokorelasi bertujuan untuk menguji apakah dalam model regresi linear ada korelasi antara kesalahan pengganggu pada periode $\mathrm{t}-1$ (sebelumnya).Jika terjadi korelasi, maka dinamakan ada problem autokorelasi. Autokorelasi muncul karena observasi yang berurutan sepanjang waktu berkaitan satu sama lainnya. Masalah ini timbul karena residual (kesalahan pengganggu) tidak bebas dari satu observasi ke observasi lainnya (Ghozali, 2013). Pada penelitian ini uji statistik yang dipergunakan untuk uji autokorelasi adalah uji Durbin-Watson.

3. Analisis Regresi Linear Sederhana

Analisis regresi digunakan untuk menguji pengaruh variabel independen Tax Avoidance terhadap Nilai Perusahaan. Model regresi yang digunakan 
untuk menguji hipotesis-hipotesis yang telah dirumuskan menggunakan metode statistik regresi linear sederhana, yaitu:

$\mathrm{Y}=\alpha+\alpha_{1} \mathrm{X}_{1}$

Keterangan:

Y : Nilai Perusahaan

$\alpha \quad$ : konstanta

$\beta_{1 \ldots} \beta_{4}$ : koefisien arah regresi

$\mathrm{X}_{1} \quad$ : Tax avoidance

E : kesalahan pengganggu (disturbance's error)

\section{Hasil dan Pembahasan}

a. Statistik Deskriptif

\begin{tabular}{lccc}
\hline & Mean & Std. Deviation & N \\
\hline TOBINSQ & .7980 & .43759 & 105 \\
CETR & .3482 & .19241 & 105 \\
\hline
\end{tabular}

Tabel 4.1

Descriptive Statistics

Dari tabel 5.1 dapat di simpulkan nilai perusahaan dari 105 perusahaan yang menjadi sampel mempunyai rata-rata nilai sebesar 0.7980 dan Tax avoidance mempunyai nilai rata-rata sebesar 0.3482 .

b. Uji Normalitas

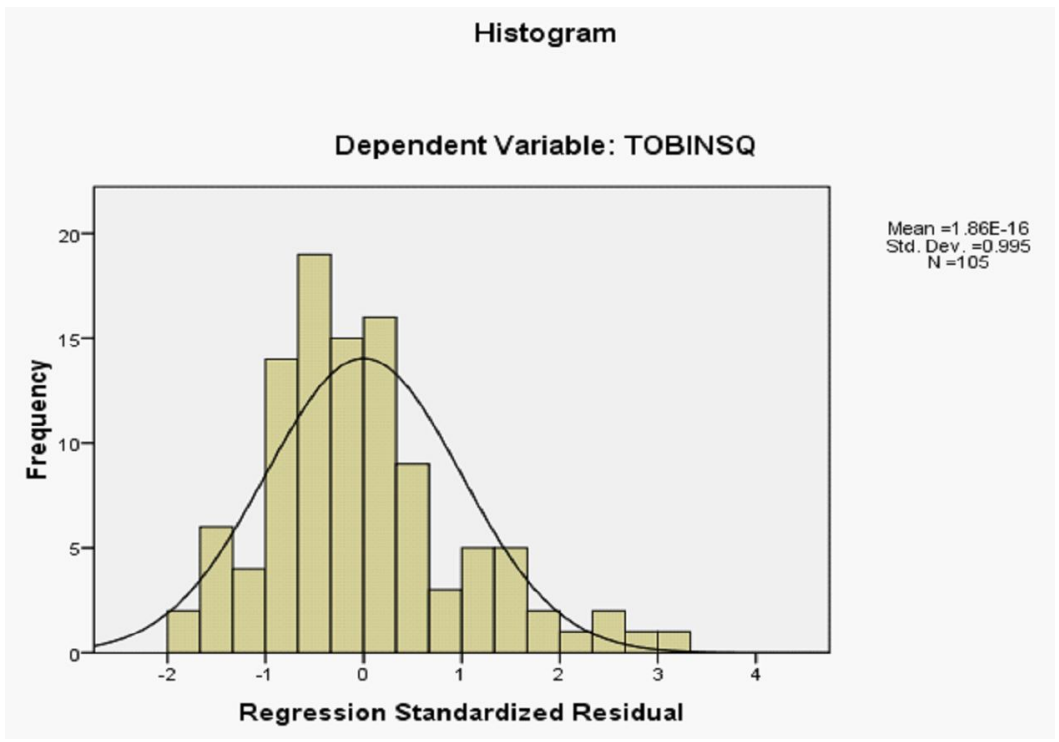

c. Uji Heterokedastisitas

Uji Heteroskedastisitas bertujuan untuk menguji apakah dalam sebuah model regresi, terjadi ketidaksamaan varians dari residual dari suatu pengamatan ke pengamatan lainnya tetap, maka disebut homoskedastisitas. Dan jika varians berbeda, maka disebut heteroskedastisitas. Model regresi yang baik adalah tidak terjadi heteroskedastisitas (Ghozali, 2013:134). Dari grafik scatterplot terlihat titik menyebar secara acak serta tersebar baik di atas maupun di bawah angka 0 pada sumbu Y. Hal ini dapat disimpulkan bahwa tidak terjadi heteroskedastisitas pada model regresi, sehingga model regresi layak dipakai untuk memprediksi setiap variabel dependen berdasarkan variabel-variabel independen. 
Pengaruh

Tax

Avoidance...

904
Scatterplot

Dependent Variable: TOBINSQ

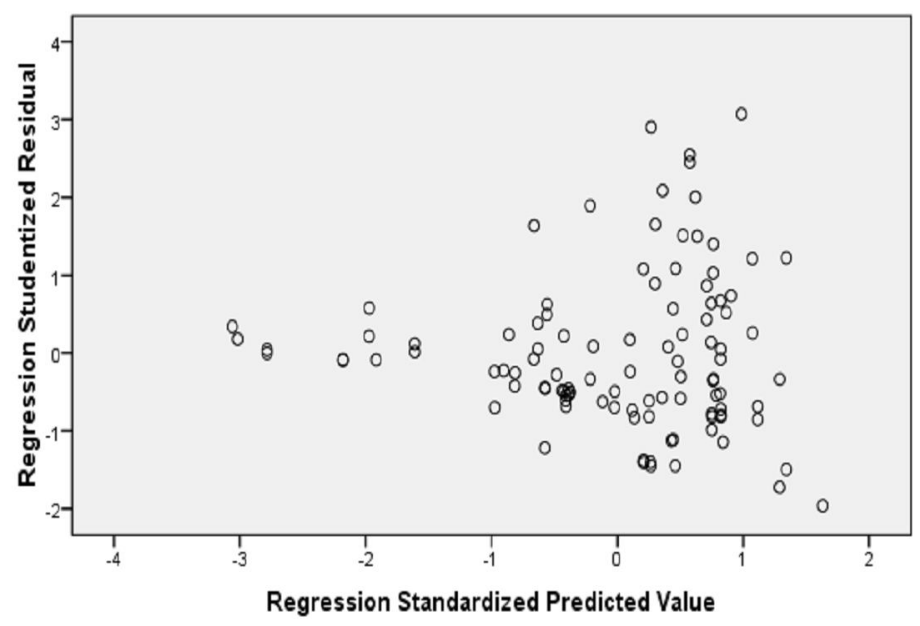

d. Uji Autokorelasi

Dalam penelitian ini pengujian asumsi klasik autokorelasi dilakukan dengan pendekatan Durbin-Watson Statistik (DW). Tujuan pengujian autokorelasi adalah untuk melihat apakah ada korelasi antara data observasi. Jika du $<\mathrm{d}$ $<4$-du maka tidak terjadi autokorelasi, baik positif maupun negative dari model regresi. Hasil pengujian menunjukkan bahwa pada tingkat signifikasi $5 \%$ diperoleh hasil $\mathrm{du}=1,7881 ; \mathrm{d}=1,965 ; 4$-du $=2,211$ sehingga $1,7881<1,965$ $<2,035$. Hasil tersebut menunjukkan bahwa tidak terjadi masalah autokorelasi.

e. Uji Statistik t

Uji t dapat dilakukan dengan melihat nilai signifikansi t masing-masing variabel pada pada output hasil regresi menggunakan SPSS dengan significance level $0,05(\alpha=5 \%)$. Jika nilai signifikansi lebih besar dari á maka hipotesis ditolak (koefisien regresi tidak signifikansi), yang berarti secara individual variabel independen tidak mempunyai pengaruh yang signifikan terhadap variabel dependen. Jika nilai signifikansi lebih kecil dari $\alpha$ maka hipotesis diterima (koefisien regresi signifikan), berarti secara individual variabel independen mempunyai pengaruh yang signifikan terhadap variabel dependen.

\begin{tabular}{|c|c|c|c|c|c|c|}
\hline \multicolumn{7}{|c|}{ Coefficients $^{a}$} \\
\hline & \multirow{2}{*}{ Model } & \multicolumn{2}{|c|}{$\begin{array}{l}\text { Unstandardized } \\
\text { Coefficients }\end{array}$} & \multirow{2}{*}{$\begin{array}{c}\begin{array}{c}\text { Standardized } \\
\text { Coefficients }\end{array} \\
\text { Beta }\end{array}$} & \multirow[t]{2}{*}{$\mathrm{t}$} & \multirow[t]{2}{*}{ Sig. } \\
\hline & & B & Std. Error & & & \\
\hline \multirow[t]{2}{*}{1} & (Constant) & 1.140 & .080 & & 14.183 & .000 \\
\hline & CETR & -.981 & .202 & -.431 & -4.852 & .000 \\
\hline
\end{tabular}

a. Dependent Variable: TOBINSQ

Berdasarkan hasil uji statistik t bahwa variabel Tax Avoidance berpengaruh signifikan terhadap Nilai Perusahaan dimana bahwa tingkat signifikansi 0,000 dibawah nilai signfikansi 0,05 . Hal ini berarti hipotesis diterima bahwa tax avoidance berpengaruh signifikan terhadap nilai perusahaan. Nilai koefisien sebesar -0.981 yang berarti bahwa semakin tinggi tax avoidance maka semakin rendah nilai perusahaan. Tindakan tax avoidance yang dilakukan oleh perusahaan, menunjukkan bahwa tindakan tax aggressiveness dapat mening- 
katkan atau menurunkan nilai saham perusahaan. Jika tax aggressiveness dipandang sebagai upaya untuk melakukan tax planning dan efisiensi pajak, maka pengaruhnya positif terhadap nilai perusahaan. Namun jika dipandang sebagai tindakan non compliance, hal tersebut akan meningkatkan risiko sehingga mengurangi nilai perusahaan (Hanlon dan Slemord, 2009).

\section{KESIMPULAN DAN SARAN}

\section{Kesimpulan}

Berdasarkan hasil analisis dan pengujian hipotesis di atas, maka diperoleh kesimpulan bahwa Variabel Tax avoidance berpengaruh signifikan negatif terhadap nilai perusahaan, yang berarti bahwa semakin tinggi tax avoidance maka semakin rendah nilai perusahaan yang berarti bahwa semakin tinggi tax avoidance maka semakin rendah nilai perusahaan. Penelitian ini hanya mengambil obyek perusahaan manufaktur dan diperolah 35 perusahaan yang memenuhi kriteria pengambilan sampel yang ditetapkan. Jumlah tersebut dikalikan 3 tahun rentang waktu penelitian sehingga diperoleh data 75 perusahaan berdasar laporan tahunan (annual report) yang dipublikasikan

\section{Saran}

Bagi investor dapat melakukan evaluasi terhadap kinerja manajemen sehingga diharapkan dapat meningkatkan nilai perusahaan (firm value) secara positif, Peneliti selanjutanya dapat memperluas obyek penelitian, sehingga diperoleh jumlah sampel yang lebih banyak dalam rangka mengantisipasi berkurangnya jumlah yang disebabkan data yang tidak nomal

\section{DAFTAR PUSTAKA}

Chasbiandani, T dan Martini, D. (2012). 'Pengaruh Tax Advoidance Jangka Panjang Terhadap Nilai Perusahaan'. Simposium Nasional Akutansi XV Banjarmasin

Chen, Xundong. Dkk. (2013). Tax Avoidance and Firm Value: Evidance from China. Nankai Business Review. Vol 3 No 1

Desai dan Dharmapala. (2009). Corporate tax avoidance and firm value. The $R e^{-}$ view of Economics and Statistics. 91 (3), $537-546$

Dyreng, Scott, Michelle Hanlon dan Edward Maydew. (2008). Long run corporate tax avoidance. The Accounting Review.83 (1). 61 - 82

Hanlon, Michelle, Shane Heitzman. (2010). A review of tax research. Journal of Accounting and Economics.50 (2010). 127 - 178.

Hanlon, Michael, Joel Slemrod. (2009). What tax aggressiveness signal? Evidance from stock Price reaction to news about tax selter involvement. Journal of Public Economics 93. Pp 126 - 141.

Ilmiani, A dan Catur Ragil Sutrisno. (2013). Pengaruh Tax Avoidance Terhadap Nilai Perusahaan Dengan Transparansi Perusahaan Sebagai Variabel Moderating. Jurnal Ekonomi dan Bisnis. Pekalongan

Indonesia, Undang-Undang 2007, Undang-undang Republik Indonesia nomor 28 tahun 2007 tentang Ketentuan Umum dan Tata Cara Perpajakan, Jakarta

Jensen dan Meckling (1976). Theory of the firm: Managerial behavior, Agency cost and Ownership structure. Journal of Financial Economics, 3, 4, $305-360$.

Resmi, S 2013, Perpajakan: Teori dan Kasus. Jakarta. Salemba Empat.

Sekaran, U 2006, Research Methods For Business (Metodelogi Penelitian Untuk Bisnis), Jakarta 
Pengaruh Suandy, E 2011. Hukum Pajak. Jakarta. Salemba Empat.

Tax

Wang, Tina. (2010). Tax avoidance, corporate transparancy and firm value. UniAvoidance... versity of Texas at Austin.

Zain, Mohammad. 2007. Manajemen Perpajakan. Jakarta: Salemba Empat, Edisi 3.

906 